\title{
BIZANTYJSKIE „ZAPEVI” ${ }^{11}$ WSPÓŁCZESNEGO TEATRU BUtGARSKIEGO. TEKSTY, KONTEKSTY, FIGURY
}

\author{
Abstract \\ THE BYZANTINE "CHANTS" OF THE CONTEMPORARY BULGARIAN THEATRE \\ TEXTS, CONTEXTS, FIGURES
}

The article is dedicated to the problems of historical drama, one of the ways of interpreting the past. The study is placed in the context of the sociology of culture and the historical memory of society, with a focus on the transposition and the symbolical representation of the history of Byzantium and the Second Bulgarian Kingdom (1181-1396) in literature. The subject of the analysis are the works of the Bulgarian poet and playwright Radko Radkov (1940-2009), above all his play Theophano, written in the convention of classical drama in verse and the so-called ritual drama, according to the title of the author, a synthesis of text borrowed from Old Bulgarian Literature, and Byzantine hymnography, inspired visually by the images of the Middle Age Miniatures included in Manassij's Chronicle (Codex Vaticanus Slav II) - Praise of Turnovgrad and In Praise of the Word. The historical theme in the work of Radko Radkov is substantially different from the interpretation of the Bulgarian history of other Bulgarian writers of the second half of the $20^{\text {th }}$ Century, by which the author is opposing the ideological constructs of the official authorities during this period. Within the discourse of the relations between creator and authorities, attention is paid to some events surrounding the 1300 anniversary of the creation of the Bulgarian state (celebrated in 1981), when, thanks to the benevolence of Lyudmila Zhivkova and the open culture policy that she, as Chairperson of the Committee of Arts and Culture, had introduced, the plays of Radko Radkov were allowed to be staged in the theatres. The playwright has found semiotic and stylistic devices that recreate the classical past of the people, the orthodox Christianity and culture in the universal perspective of the Byzantine Commonwealth, and artistically voice his historiosophic views concerning Bulgarian national history and the Byzantine-Bulgarian cultural community. The paper analyses the tribulations of the performance of Theophano, staged in Bulgaria by the French Director Pierre Della Torre, who sees in the poetic world of Radko Radkov "the monumental force of the masters of French theatre, Racine and Corneille".

1 Tytuł referatu nawiązuje do nazwy tomiku poetyckiego Radkova, Bizantyjskie „zapevi”. Źródła inspiracji autora należy szukać w hymnografii, gdzie „zapev” oznacza początek muzycznego fragmentu, zaintonowanie, semantycznie odnosi się do genetycznej jedności rodowodu muzyki oraz słowa poetyckiego. 
SŁOWA KLUCZE: Teatr bułgarski (wiek XX), Radko Radkov, Theophano, Byzantine Commonwealth, pamięć historyczna, jubileusz 1300 lat państwa bułgarskiego (1981)

KEY WORDS: Bulgarian Theatre (20th Century), Radko Radkov, Theophano, Byzantine Commonwealth, historical memory, Anniversary 1300 years Bulgarian state (1981)

Kultura i literatura stanowią przestrzeń duchową, w której następuje konfrontacja rozmaitych politycznych oraz ideologicznych założeń i relacji ${ }^{2}$. Wyobrażanie oraz samo myślenie o przeszłości są fikcyjne w kontekście badań Clifforda Geertza. Postrzegał on pamięć historyczną relatywnie - jako koncept tworzony w ramach poszczególnych społecznych lub państwowych strategii ${ }^{3}$. Fikcyjność w ujęciu Geertza nie jest jednak równoznaczna z jej ahistorycznością, nie oznacza też fałszywych lub nieprawdziwych relacji wydarzeń, a jedynie to, że są one konstruktem, ukształtowanym w określonym systemie obowiązujących zasad rozumienia dziejów. Dramat historyczny zawsze był jedną z form oswajania przeszłości, sposobem tworzenia rzeczywistości potencjalnie możliwej ${ }^{4}$. Dzieła sceniczne bułgarskiego poety i dramatopisarza Radko Radkova (1940-2009) wychodzą poza zwykłe obrazowanie literackie, a w niedalekiej przeszłości (przed rokiem 1989) Radkowski teatr modelował historyczne światy przedstawione, odmienne od obowiązującej wtedy interpretacji i estetyki. Do dziś kształtuje on w sposób oryginalny myślenie i wyobrażenia o bułgarskim średniowieczu, przede wszystkim przez konceptualizację uniwersalnej problematyki dziejów Byzantine Commonwelth ${ }^{5}$, łączenie historycznej empirii, tekstów literatury starobułgarskiej oraz liturgii prawosławnej.

Historyczno-literacki i narracyjny charakter interpretacji tematu w artykule oraz umieszczenie go w perspektywie socjologii kultury warunkują metodologiczny wybór zastosowany w analizach utworów i biogramu poety. Podejmowane zagadnienia

2 Zob. E.W. Said, Kultura i imperializm, tłum. M. Wyrwas-Wiśniewska, Kraków 2009, s. 73.

${ }^{3}$ Zob. C. Geertz, Interpretacja kultur. Wybrane eseje, thum. M.M. Piechaczek, Kraków 2005, s. 28-33. Pamięć, mimo całej jej „fikcyjności”, zawsze jest związana z tożsamością jednostki. W walce o zachowanie pamięci historycznej, symbole i figury historyczne, sposoby ich przedstawiania, w tym również wymowa emocjonalna autora, odgrywają ważną rolę w dziele o tematyce historycznej. Symboliczne filary wiążą pamięć jednostki z pamięcią ogółu, wspomagają jej kontinuum przez przypominanie lub wizualizację podczas jubileuszowych rocznic, w monumentach, pomnikach i rytuałach.

${ }^{4}$ Sztuki teatralne zajmują w kulturze bułgarskiej ważną pozycję i cieszą się do dzisiaj wielką popularnością wśród publiczności. Poczynając od okresu Bułgarskiego Odrodzenia Narodowego (od XVIII do XIX wieku), dramat historyczny pełnił znaczącą rolę w procesie pobudzenia i uformowania świadomości narodowej Bułgarów. Zob. В. Стефанов, История на българския театър. От зараждането до 1878 г., т. I, София 1997; Г. Саев, История на българския театър. От Освобождението до 1904 г., т. II, София 1997; Кр. Тошева, История на българския театър. Om 1904 до 1918 г., т. III, София 1997; Н. Йорданов, Р. Попилиев, К. Николова, В. Дечева, История на българския театър, т. IV, София 2011.

5 Zob. klasyczną monografię: D. Obolensky, The Byzantine Commonwealth: Eastern Europe, 500-1453. History of Civilization, London 1971; w języku polskim: G. Ostrogorski, Dzieje Bizancjum, thum. pod red. H. Ebert-Kappesowej, Warszawa 1968. Pojęcie „Byzantine Commonwelth”, przywołujące wzór Brytyjskiej Wspólnoty Narodów, jednak nie oddaje całej specyfiki bizantyjsko-słowiańskich związków. 
rozpatrywane są zarówno na płaszczyźnie historii teatru, jak i w dyskursie znakowości dziejów, symbolizacji wydarzeń z przeszłości, postaci lub artefaktów. Polityczne konteksty zarządzania w kulturze z ostatnich dziesięcioleci XX wieku w Bułgarii, dotyczące zbiorowej pamięci historycznej, ukazują działania rządzącej wtedy formacji politycznej, ukierunkowane na ,przebudowę” pamięci społeczeństwa i wizji dziejów narodowych. Niektóre aspekty drogi życiowej i twórczości Radko Radkova odsłaniają mechanizmy, kierunek i narzędzia ideologicznego zarządzania kulturą i sztuką oraz procesy indywidualnego przeciwstawiania się nakazom odgórnym, „wychylenia się” spod opieki cenzury.

Jak na czasy ,realnego socjalizmu” Radko Radkov był twórcą niezwykłym. Wyjątkowość jego dokonań artystycznych polegała również na tym, że znalazł obrazowe i stylistyczne figury, reprezentujące dziejowe „koncepty” klasycznej przeszłości kulturowej wspólnoty bizantyjsko-bułgarskiej oraz Drugiego Carstwa Bułgarskiego (1181-1396). Pierwszą swoją sztukę pod tytułem Baldwin I Flandryjski napisał już jako osiemnastoletni uczeń w Prawosławnym Seminarium Duchowym im. św. Ivana Rylskiego. Wszyscy, którzy mieli z nim styczność, odbierali poetę jako wyjątkowo utalentowanego twórcę, geniusza, głęboko wierzącego człowieka ${ }^{6}$. Za życia doczekał się uznania we Francji, został kawalerem srebrnego Krzyża Akademii Francuskiej, orderu kultury francuskiej, dwukrotnym laureatem literackiej Nagrody Napoleońskiej (1983, 2005), Grand Prix International Solenzara de Poésie, między innymi za dramat Theophano ${ }^{7}$.

Sztuki o tematyce historycznej Radkova oraz tzw. dramaty rytualne, według tytulatury samego autora (Mowa pochwalna na cześć Słowa, Stowo o Tyrnovgradzie ${ }^{8}$ ),

${ }^{6}$ Radko Radkov, będąc absolwentem filologii klasycznej, posługiwał się płynnie językiem starobułgarskim, greką i łaciną. Jego przyjaciele twierdzą, że znał ponad dziesięć tysięcy wierszy, z czego dużą część recytował we wspomnianych językach klasycznych. Zob. wspomnienia jego wieloletniego przyjaciela, francuskiego poety bułgarskiego pochodzenia, Athanase Vantchev de Thracy, http://institutcultureldesolenzara.org/ancien/radkov.html [odczyt: 4.05.2016].

7 Autor urodził się w średniowiecznej stolicy Bułgarii, w Wielkim Tyrnowie. W latach pięćdziesiątych XX w. ukończył Prawosławne Seminarium Duchowe w Čerepišu, a później - filologię klasyczną na Sofijskim Uniwersytecie im. św. Klimenta Ochrydzkiego. Radko Radkov jest autorem dwudziestu pięciu dramatów o tematyce historycznej, między innymi: Theophano, Św. Eutymiusz Patriarcha Tyrnowski, Joan Kukuzelis Angieloglasnyj, Car Symeon Wielki. Tragedia triumfatora, Car Seuthes III. Misterium. Heroika, Przygody Ateny, Ogólne narodowe czuwanie ku czci Apostoła i in.; dramatu Ostatnia wieczerza poświęconego malarstwu Leonarda da Vinci; dramatów rytualnych: Mowa pochwalna na cześć Stowa, Mowa pochwalna o Tyrnovgradzie i in.; tomików poetyckich: Bizantyjskie zapevi, Sonety miłosne, Carskie sonety miłosne i in. (tłum. tytułów na język polski - G.S.K.). Po roku 1989 opublikował kilka książek, między innymi Butgarski Satyrykon. Otrzymał następujące nagrody: za sztukę Baldwin I Flandryjski w 1985 r. został Kawalerem Orderu Kultury Francuskiej; Synod Bułgarskiego Kościoła Prawosławnego odznaczył poetę orderem „Sveti Sofronij Vrachanski” - pierwszego stopnia. Radkov pracował jako wykładowca języków klasycznych na uniwersytecie w Wielkim Tyrnowie i w Instytucie Bałkanistyki Bułgarskiej Akademii Nauk. Zob. też Св. Бинева, Моят Радко и приятели. Мемоарна книга 1963-2008, София 2008.

${ }^{8}$ Sztuka Mowa pochwalna na cześć Stowa została wystawiona najpierw w Teatrze Dawnym w Wielkim Tyrnowie w 1978 r., utwór sceniczny Stowo o Tyrnovgradzie powstał jako adaptacja dla teatru telewizji w $1979 \mathrm{r}$. 
powstały w konwencji literackiej wierszowanego dramatu klasycznego. Pod nazwą, można by rzec, tego podgatunku sztuki historycznej kryją się utwory o strukturze mieszanej, pewien rodzaj połączenia tekstów średniowiecznych i autorskich, kompozycje o charakterze poetycko-dramaturgicznym lub nawet inspirowane miniaturami średniowiecznymi, bizantyjskimi i starobułgarskimi. Radko Radkov daje czytelnikowi możliwość przynajmniej częściowej weryfikacji wydarzeń w aspekcie historiozoficznym, stawiając akcent na myśleniu symboliczym, charakterystycznym dla człowieka epoki średniowiecza. W jego sztukach koegzystują dwa plany kreacji artystycznej - historyczny i semiotyczny. Pierwszy - skupia się na wydarzeniach, na psychologicznej motywacji działań postaci, drugi zaś ma charakter kulturologiczny, umocowany jest w fikcyjnym świecie teatru, bohaterów, fabuł i został ukształtowany przez historyczną pamięć autora, podporządkowaną zarówno wymogom gatunku, jak i pewnemu szczególnemu dyskursowi pamięci emocjonalnej. Powody reaktywacji wspomnianego dyskursu tkwiły w syndromie zapomnienia i manipulacji dziejów narodowych w Bułgarii po roku 1944, jego intensywność prowokowana była polityką marginalizowania znaczenia średniowiecznego carstwa bułgarskiego i jego kultury, zatarcia ich chrześcijańskiej istoty oraz zafałszowania pamięci o nich. Stała obecność idiolektów odsuwała w przeszłość wertykalną konstrukcję pamięci kulturowej, dla której przestrzenią ekspresji były m.in. literatura i kultura starobułgarska. Dotyczy to również prawosławnych tradycji narodu i Kościoła, świadomie pomijanych lub wręcz prześladowanych. Niektóre kwestie konstruowania pamięci i tożsamości z punktu widzenia płynności przekazu historycznego poruszyła w swoich badaniach Alejda Assman9. Większa część wspomnień „drzemie” - użyjmy wyrażenia Marcela Prousta - w nas, by przebudzić się za sprawą zewnętrznego impulsu ${ }^{10}$. We współczesnych dziejach Bułgarii dla społeczeństwa takim impulsem był jubileusz 1300-lecia założenia państwa bułgarskiego, obchodzony w roku 1981 (681-1981). Jeśli wracam do tych wydarzeń, to przede wszystkim z powodu biografii twórczej Radkova.

Odwilż społeczno-kulturalna lat sześćdziesiątych XX wieku, a później - na przełomie lat siedemdziesiątych i osiemdziesiątych to najbardziej aktywny okres dla pisarza. W ciągu pięciu lat (1977-1981), właśnie z okazji wspomnianego jubileuszu, wyszedł on z twórczego niebytu, zaś niektóre jego utwory trafiły do szerszego grona czytelników. Należy zaznaczyć, że obchody 1300-lecia państwowości bułgarskiej w dużej mierze zawdzięczały swoją rangę i rozmach ówczesnej przewodniczącej Komitetu Kultury i Sztuki Ludmile Zhivkovej (1942-1981) ${ }^{11}$ oraz grupie zebranych

9 A. Assman, Między historia a pamięcia. Antologia, M. Saryusz-Wolska (red.), Warszawa 2013, s. 40.

10 Tamże, s. 41-42.

${ }^{11}$ Ludmila Zhivkova, córka pierwszego sekretarza bułgarskiej partii komunistycznej Todora Zhivkova (1911-1998), z wykształcenia była historykiem, w Oksfordzie zrobiła specjalizację w dziedzinie historii sztuki. Od 1973 r. stała na czele Komitetu Kultury i Sztuki i prowadziła bardziej niezależną i otwartą na Zachód politykę kulturalną, z silnymi akcentami narodowymi. Podejmowała różne inicjatywy na rzecz popularyzacji kultury bułgarskiej w Europie i na świecie (głównie w Japonii, Indiach, Ameryce Łacińskiej, w krajach Bliskiego Wschodu). W 1978 r. została doktorem honoris 
wokół niej intelektualistów ${ }^{12}$. Potężny wydźwięk jubileuszu w społeczeństwie pokazał, jak silna jest interakcja między ludzką pamięcią a wydarzeniami kulturowymi i historycznymi czy artefaktami. Dawna kultura i literatura bułgarska zostały wówczas na pewien okres oficjalne zrehabilitowane, także ich treści chrześcijańskie. Do tego momentu utwory teatralne Radko Radkova całymi latami czekały na wystawienie, niedopuszczane na scenę przez cenzurę, ponieważ prezentowały poglądy sprzeczne z oficjalną metanarracją dziejów narodowych ${ }^{13}$.

Sztuka historyczna Theophano, napisana w 1972 roku, jest jednym z jego najbardziej znanych i rozpoznawalnych utworów. Dopiero dziewięć lat później, z okazji 1300-lecia państwowości bułgarskiej, władze wyraziły zgodę na wystawienie dramatu na scenie Teatru Dramatycznego im. Bojana Danovskiego w industrialnym mieście Pernik, niedaleko Sofii. Żaden z teatrów w stolicy, pod różnymi pretekstami, nie zdecydował się włączyć sztuki do swojego repertuaru. Komitet Kultury i Sztuki zaprosił znanego francuskiego reżysera teatralnego Pierre'a Della Torre ${ }^{14}$, aby wystawił sztukę Theophano. W wywiadzie udzielonym po swoim przybyciu do Bułgarii Della Torre powiedział o sztuce Radkova:

$\mathrm{Z}$ dużym zainteresowaniem zapoznałem się z dramatem Radko Radkova. W jego poetyckim świecie odkrywam coś z wielkich mistrzów francuskiego teatru klasycznego, Racine'a i Corneille'a. Coś monumentalnego. Theophano ujęła mnie, wzruszyła prawdziwością bohaterów, głębokim sensem filozoficznym. Moim zdaniem ten dramat bardzo przypadnie do gustu również francuskiemu widzowi ${ }^{15}$.

Radkov, pisząc Theophano, korzystał z kilku źródeł historycznych, głównie - według moich ustaleń - z opracowania Figures Byzantines znanego francuskiego

causa Uniwersytetu w Tokio. Była zainteresowana literaturą starobułgarską i kulturą chrześcijańską, starożytną Tracją, badaniami archeologicznymi. W życiu prywatnym nie ukrywała swoich fascynacji buddyzmem i filozofią Dalekiego Wschodu. Do momentu jej śmierci (wokół której powstały różne teorie spiskowe) Radko Radkov miał wielką protektorkę. Działalność i postać L. Zhivkovej budziły w Bułgarii kontrowersje i polityczne spory, była ona krytykowana, przed i po 1989 r., oczywiście z pozycji odmiennych założeń ideowych. Na temat bułgarskiej polityki kulturalnej przełomu lat siedemdziesiątych - osiemdziesiątych XX w. zob. między innymi: Е. Александров, Култура и лична власт. Аз работих с Людмила, София 1991, s. 25-116.

12 Skala i formy jubileuszowych imprez, ich wymowa historyczna (mało prawdopodobne, iż takie były zamierzenia organizatorów partyjnych) faktycznie obnażyły, a tym samym sprzeciwiły się procesowi wynarodowienia, realizowanemu w postaci oficjalnej doktryny tzw. internacjonalizmu, propagowanego przez ideologię komunistyczną.

${ }_{13}$ Przykładowo: krytycy normatywni zarzucali jego sztuce pod tytułem Święty Eutymiusz Patriarcha Tyrnowski, poświęconej przywódcy Kościoła bułgarskiego z XIV wieku, niewłaściwe przedstawienie walki narodowej przeciwko tureckiemu najeźdźcy. Według nich dramat sam w sobie stanowił przede wszystkim apologię prawosławia.

${ }^{14}$ W tym czasie reżyser prowadził, założony przez siebie, Théatre du Val de Marne w Saint-Maur-des-Fossés. Przekładu sztuki na język francuski dokonał w Paryżu Athanase Vantchev de Thracy.

15 Ц. Стойчева, Ел. Митева, Интервю, „БТА-Паралели”, 17-23 декември, 1981, с. 6. Zob. też: Г. Рашееева, Френски режисьор ще постави българска пиеса в театър „Боян Дановски”, „Димитровско знаме”, 17 юли 1981, s. 4. 
historyka Charles'a Diehla ${ }^{16}, \mathrm{z}$ greckich kronik Leona Diakona ${ }^{17}$ i starobułgarskiego opowiadania z XIV wieku pt. Szynkareczka Theofano ${ }^{18}$. W tekście ludowego przekazu istnieje jednak wyraźny element mizoginiczny, który został pominięty w sztuce. Autor nie podążał śladem czarnej legendy, stworzył dzieło poświęcone wiecznej kobiecości, sile ludzkiego charakteru i namiętności, jednocześnie pokazując mechanizmy rządzenia. W zewnętrznej, obrazowo-plastycznej warstwie fabuły zawarta została przyciągająca uwagę opowieść o Anastasso. Była ona córką plebejusza rodem z Lakonii, właściciela oberży, o imieniu Kraterus, która dzięki swej urodzie, zrządzeniu losu i szczęśliwemu przypadkowi wspięła się na wyżyny społeczne, zostając bizantyjską cesarzową - Theophano (około 936-991). Według słów samego autora, jego dramat jest ,,apoteozą kobiety i piękna kobiecego, tryumfu jej ducha i wewnętrznej wolności. Kobiety, której piękno przełamuje kanony ówczesnego greckiego społeczeństwa"19.

Rolę młodej cesarzowej francuski reżyser powierzył debiutantce Marii Kavardzikovej, co także było niespotykaną praktyką w bułgarskich teatrach owego czasu. Scenariusz reżyserski oparto na bogatej grze pantomimicznej, robiących wrażenie mise-en-scène zanurzonych w poetyckim wielosłowiu dramatu. Po pierwszych przedstawieniach rozpętał się skandal wokół tej inscenizacji, glównie przez „nieideową", wręcz hollywoodzką widowiskowość, jak to wtedy ujęto. Podnoszono zarzuty, że autor skupił się wyłącznie na fabule, oraz krytykowano sceny z ,kąpiącą się nago" cesarzową w cesarskich komnatach, nie do przyjęcia dla ówczesnej władzy. Aktorka i spektakl stały się symbolem naruszenia socjalistycznej obyczajowości. Można tylko żałować, że nie posiadamy nagrania przedstawienia, mimo że

${ }^{16}$ Ch. Diehl, Théophano [w:] Figures Byzantines, Paris 1906, s. 217-243.

17 Лъв Дякон, История, Увод, превод и бележки Г. Цанкова [w:] Гръцки извори за българската история (Fontes graeci historiae Bulgaricae), т. V, Ив. Дуйчев (ред), София 1964, s. 245-276 (257-258).

18 Szynkareczka Theofano, thum. T. Dąbek-Wirgowa [w:] Siedem niebios i ziemia. Antologia dawnej prozy bułgarskiej, wstęp i thum. T. Dąbek-Wirgowa, Warszawa 1983, s. 149-151; Oryginalna publikacja w j. bułg.: Й. Иванов, Крьчмарка Теофана [w:] Старобългарски разкази. Разказ за цар Фока и за братята му, как ги погуби в една нощ крьчмарката Теофана, София 1936, s. 187-189; Bohaterka Radkova ma wiele wspólnego z szekspirowskimi postaciami, przeżywa ona rozmaite perypetie, miotana namiętnościami oraz intrygami: traci męża, kochanka i koronę. W $956 \mathrm{r}$. Theophano (vel Anastasso) została cesarzową Wschodniego Cesarstwa Rzymskiego (Bizancjum) po ślubie z jedynym synem Konstantyna VII Porfirogenety (945-957), młodym Romanem II (959963). Po jego śmierci, utalentowany dowódca wojskowy Nikephoras Phocas (963-969) poją ją za żonę i wstąpił na tron. Kilka lat później w wyniku spisku cesarz Phocas został zamordowany w pałacu przez generała Joana Tzimiskesa, domniemanego kochanka cesarzowej. Jednak po przewrocie pałacowym Tzimiskes porzucił Theophano, która dożyła końca swych dni w klasztorze. Na temat jej pochodzenia nie ma wiarygodnych źródeł historycznych. Nadworni kronikarze starali się zachować dobre imię dynastii i twierdzili, że wywodziła się ze starego szlacheckiego rodu. Według bizantyjskich historyków jej rodowód był nader skromny. Jednakże wszyscy współcześni byli jednomyślni co do jej urody, określanej jako „niezwykła”, „nadludzka”, wręcz boska. O tych wydarzeniach pisze w swojej Historii Leon Diakon. Wokół jej postaci narosła czarna legenda, uważano ją za kobietę fatalną, ściągającą nieszczęście, ukoronowaną heterę.

19 Г. Рашеева, Интересен творчески експеримент, „Димитровско знаме”, 8 август, 1981, s. 4. 
było wystawiane ponad dwieście razy w wypełnionych po brzegi salach teatralnych, w tym - w zachowanym z czasów rzymskich amfiteatrze w Płowdiwie przed czterotysięczną publicznością ${ }^{20}$.

Na temat spektaklu w Perniku, mimo jego niezwykłości jak na warunki życia teatralnego kraju w tym okresie, ukazały się tylko trzy recenzje, został on objęty zmową milczenia w prasie. W krytycznym tekście opublikowanym pół roku po premierze w czasopiśmie ,Teatr" ${ }^{21}$, podstawowymi zarzutami pod adresem inscenizacji Pierre'a Della Torre były: celowe dążenie do „widowiskowości kompozycji” i ,zbyt duża dynamika konstrukcji"22 spektaklu:

Przedstawienie zostało zbudowane według wypróbowanych zasad teatru widowiskowego [...], wszyscy lubią oglądać dramaty miłosne. [...] Fabuła stanowi żywioł dramatu Theophano, a nie ma wdzięczniejszego tematu niż historia bizantyjskiego dworu, gdzie na żonę cesarza została koronowana piękność z przybrzeżnej tawerny ${ }^{23}$.

Jeśli francuskiemu reżyserowi zaoszczędzono więcej uwag, to lista zarzutów pod adresem Radkova była długa. Na nieprzychylność recenzji na pewno miała wpływ zmiana politycznej i kulturalnej koniunktury po 1981 roku ${ }^{24}$. Poeta był krytykowany nawet za wierszowaną formę utworu, a głównie - za „niewspółczesny temat” i brak związku sztuki z aktualną rzeczywistością: „Naprawdę interesująca fabuła, tyle że na pytanie, jaki ma związek z nami dzisiaj, oprócz bliskości geograficznej miejsca akcji, trudno jest odpowiedzieć..."25. Pierre Della Torre miał zupełnie inne zdanie i w jednym ze swoich wywiadów zwrócił uwagę na uniwersalne treści, a jednocześnie aktualność podejmowanych tematów w dramatopisarstwie Radkova:

Radkov potrafi posługiwać się historią, aby podejmować współczesne i wieczne problemy - są to pytania o miłość, o władzę, o wolność. Autor ten posiada wyjątkowe predyspozycje do bycia poetą i autorem teatralnym! ${ }^{26}$.

$20 \mathrm{http} / /$ kulturni-novini.info/news.php?page=news_show\&nid=21695\&sid=31 [odczyt: 6.06.2016] (Wspomnienie aktora Lubomira Bachvarova). Zob. też: wywiad z byłym dyrektorem teatru Georgiem Russevem: След 65 един актьор започна да играе само себе си, http://obshtestvo.net/\%60/ [odczyt: 6.06.2016].

${ }^{21}$ Кр. Русинова, Ще се пробуди ли спящата красавица, „Театьр”, бр. 8/XXXV, София 1982, s. 40-42.

22 Tamże, s. 40.

${ }^{23}$ Tamże, s. 40.

${ }^{24} \mathrm{Na}$ zmianę w polityce kulturalnej i powrót do stagnacji, bez wątpienia wpłynęła śmierć Ludmily Zhivkovej w 1981 r. Przeprowadziłam analizę tekstów krytycznych i publicystycznych poświęconych wydarzeniom kulturalnym, opublikowanych w tygodniku kulturalnym „Narodna Kultura” w latach 1979-1982, w których łatwo można dostrzec wyraźną zmianę tematów, stylu, doboru omawianych wydarzeń kulturalnych po $1981 \mathrm{r}$.

${ }^{25}$ Кр. Русинова, Ще се пробуди ли спящата красавица, s. 40.

26 Tamże. G. Rasheeva w cytowanym artykule (zob. przypis nr 19) opisuje wizytę Pierre'a Della Torre w czerwcu 1981 r., w związku z planowanym wystawieniem Theophano w Bułgarii. Spotkał się on z dramaturgami, scenografami i aktorami, omawiając wiele kwestii organizacyjnych. „Uczyniono pierwszy krok. Regularne próby rozpoczynają się we wrześniu. Oczekujemy z niecierpliwością 
Centralne zagadnienie $\mathrm{w}$ świecie przedstawionym dramatu Theophano stanowi relacja człowieka z historią. W dramaturgicznym tekście daje się wyczuć przytłaczającą dysproporcję między jednostką a społecznością, która pośrednio prezentuje piramidalny obraz świata dawnej epoki. Radko Radkov osiągnął przekonującą wizję hierarchicznego społeczeństwa, z ukrytymi mechanizmami władzy, zbudowanego na zasadach posłuszeństwa i uległości. Czy w ustrukturalizowanym ściśle świecie w ogóle jest możliwa wolność jednostki? Byłoby jednak zbyt spektakularnym posunięciem doszukiwanie się $\mathrm{w}$ tekście bezpośrednich sugestii odnoszących się do sytuacji politycznej lat siedemdziesiątych XX wieku, choć niektóre metody rządzenia przedstawione w dramacie można odnaleźć w każdym systemie i epoce. Mimo to pisarz daje pewne wskazówki interpretacyjne idące właśnie w tym kierunku:

Moim zamiarem było stworzenie spektaklu o ponadnarodowej treści, który pokazałby wzajemne przenikanie się kultury bałkańskiej i najbardziej bolesnych problemów współczesności. [...] Temat „Theophano” ma wymiar uniwersalny... ${ }^{27}$

We wspomnianej recenzji autorka formułuje dalsze zarzuty, wskazując na jeszcze inny problem, dotyczący warsztatu gatunkowego sztuki, a mianowicie niedostosowania charakterów i konfliktów do określonych wymogów „teatru i dramaturgii”: ,[...] jednakże uniesiony swoim pełnym polotu wierszem - pisze recenzentka - autor nie liczy się ze specyficznymi dramaturgicznymi kwestiami i usilnie dąży do poszukiwania jedynie ciekawej fabuły"28. Nierozumiejącej semiotycznego klucza zastosowanego w interpretacji postaci autorce artykułu bohaterowie jawią się tylko jako maski, bez psychologicznego ujęcia:

Tutaj despota jest tylko despotą w osobie Konstantyna [...], tutaj cesarzowa jest jedynie podstępną władczynią, tu córka imperatora troszczy się jedynie o władzę... Aktorzy odgrywają jedynie to. Jedna namiętność. Jedna wola. Do tego zawsze z jednym znakiem, z jedną etykietą ${ }^{29}$.

Dalej Russinova posługuje się w swojej analizie banalnymi stereotypami, zawartymi w obrazach „bizantyjskiej podstępności”, „rozpusty”, „trucizny” itp., typowymi retorycznymi figurami antybizantynizmu. Trudno się jednak zgodzić ze stawianymi zarzutami i koniunkturowymi osądami w recenzji w kontekście wypowiedzi francuskiego reżysera, który wysoko ocenił artystyczne zalety dramatu: „Uważam, że Theophano jest wielkim i bardzo mocnym utworem. Nazwałbym Radko Radkova - współczesnym Szekspirem"30.

premiery na deskach naszego teatru, a potem występów naszych aktorów we Francji”. Do tego wyjazdu jednak nigdy nie doszło.

${ }^{27}$ Г. Рашеева, Интересен творчески експеримент.

${ }_{28}^{28}$ Кр. Русинова, Ще се пробуди ли спящата красавица.

29 Tamże.

${ }^{30}$ Г. Рашеева, Интересен творчески експеримент..., s. 4. Podobną opinię na temat twórczości dramatopisarza wyraził prof. Jean Guitton (filozof i teolog francuski, członek Akademii Francuskiej), który na zaproszenie Komitetu Kultury i Sztuki w 1981 r. przyjechał na premierę Theophano, http://www.zapernik.biz/novini/4683.html?page=13 [odczyt: 10.05.2016]. 
Twórczość pisarza pokazuje, w jakim stopniu był on uwikłany - w sposób filozoficzny i egzystencjalny - w historyczność, a jego teatr pozwalał patrzeć na dzieje, na kulturę narodową i człowieka w sposób syntetyczny. Istotnymi wyznacznikami formy wewnętrznej utworów teatralnych Radkova są czasoprzestrzeń i historyczność. Dla niego czasoprzestrzeń jest właściwością struktury świata przedstawionego, źródłem porządku, aktualizującego się w historii i życiu jednostki. Istnieje ona jako emblemat wydarzeń, pojawiający się na różnych poziomach kreacji artystycznej. Uosabia też autorskie patrzenie na teraźniejszość o charakterze esencjonalnym, które często przyjmowało postać pytań egzystencjalnych lub metafizycznych, a potrzebne odniesienia znajdowało w historyczności. Podobne ujęcie tematów Radko Radkov reprezentuje w dramatach ,rytualnych”, które tylko w pewnym stopniu rządzą się prawami gatunku teatralnego. Napisany w tej konwencji utwór Stowo o Tyrnovgradzie opracowany został na podstawie miniatur Kroniki Manassasa (Codex Vaticanus Slav II ${ }^{31}$, ilustrujących dzieje dwóch średniowiecznych carstw bułgarskich, oraz Ewangeliarza cara Ivana Aleksandra (1331-1371). Narratorzy, średniowieczny pisarz Raten i arystokratka Camblak, werbalnie obrazują wydarzenia ujęte w malarstwie miniaturowym. Akcja utworu toczy się w kontekście bułgarskiego i bałkańskiego Renesansu Paleologów oraz Carstwa Tyrnowskiego (1181-1393). Autor wkomponował w wizję słowiańsko-bizantyjskiej wspólnoty rozważania o uniwersalnym charakterze średniowiecznej bułgarskiej kultury i Tyrnowskiej Szkoły Piśmiennictwa, o kontynuacji jej duchowych osiągnięć (po zawładnięciu Półwyspu Bałkańskiego przez Turków) na innych ziemiach słowiańskich ${ }^{32}$. Radko Radkov przywrócił do świadomości społecznej i indywidualnej podstawowe figury (w pojęciu Gérarda Genette'a) rodzimej historii i kultury średniowiecznej. Ukazał piękno wschodniego chrześcijaństwa jako zjawiska estetycznego, w symbiozie słowa autorskiego oraz liturgicznego. Jak bardzo był związany ze sztuką historyczną, świadczy jego działalność. W latach siedemdziesiątych XX wieku założył w Wielkim Tyrnowie Teatr Dawny, zorientowany na repertuar historyczny i klasyczny, zostając jego pierwszym kierownikiem. W jednym $\mathrm{z}$ wywiadó $\mathrm{w}^{33}$ Radkov opowiada historię inscenizacji „dramatu rytualnego" Mowa pochwalna na cześć Stowa, który napisał na podstawie literackich tekstów starobułgarskich (X-XIV w.). Spektakl został przygotowany przez Teatr Dawny z Wielkiego Tyrnowa, a premiera odbyła się w krypcie katedry

31 Zob. Летописта на Константин Манасий. Фототипно издание на Ватиканския препис на среднобългарския превод (Biblioteca Apostolica Vaticana. Manuscript Vat. Slav II). Увод и бележки от Иван Дуйчев, Български художник, София 1963.

${ }^{32}$ Dla narracji historycznej „dramatu rytualnego” duże znaczenie miała zarówno poetyka fragmentu, jak i umiejętność postrzegania wydarzeń ze względu na ich historyczne znaczenie. Stricte literackie posunięcia, determinujące konkretne rozwiązania dramaturgiczne, ukazywały sposoby przetworzenia źródeł tekstowych i ikonograficznych w Stowo o Tyrnovgradzie. Przedstawienie, w którym wykorzystano różne środki artystyczne, zostało przyjęte przez krytykę jako eksperyment, swego rodzaju syntezę poezji, teatru i baletu. Informacje na temat inscenizacji utworu w teatrze telewizyjnym można znaleźć w publikacji M. Райчев, Опорните точки на Слово за Търновград, „Народна култура”, бр. 21, 24 май 1979, s. 6.

33 Е. Георгиева, Личности, „Над петдесет и пет”, 19 декември - 2 януари 2005, s. 12. 
św. Aleksandra Nevskiego w Sofii w 1981 roku. Inscenizacja zrobiła ogromne wrażenie na widzach, a sam autor wspomina:

Ludmiła [Zhivkova] uważała, że można wystawiać żywoty świętych w sposób dramaturgiczny. [...] Na przedstawienie Mowy pochwalnej na cześć Słowa przyszła ze swoimi dziećmi, w towarzystwie wszystkich członków Świętego Synodu ${ }^{34}$.

Należy wspomnieć też pewne wydarzenie z roku 1985, które nastąpiło w Watykanie. Wówczas rzymska prasa zapowiadała gościnny występ bułgarskiego Teatro Antico. Poetycko-dramaturgiczny spektakl Radkova Mowa pochwalna na cześć Słowa odniósł wielki sukces w Rzymie i Watykanie, gdzie Teatr Dawny z Wielkiego Tyrnowa ${ }^{35}$ był zaproszony na uroczyste obchody piątej rocznicy ogłoszenia świętych Cyryla i Metodego patronami Europy. Po zakończeniu spektaklu papież Jan Paweł II, bardzo wzruszony, wyraził swoje zdumienie, że autor zaprezentowanej sztuki jest pisarzem współczesnym, ponieważ uważał Mowę pochwalna na cześć Słowa, napisaną wierszem klasycznym na podstawie starobułgarskich tekstów liturgicznych i hymnograficznych, za utwór z okresu średniowiecza. Ówczesna prasa bułgarska w ogóle nie odnotowała ogromnego sukcesu tego przedstawienia, ukazała się jedynie sucha wzmianka: „Grupa aktorów bułgarskich odwiedziła Rzym i Watykan”36.

Historyczno-literackie poszukiwania Radko Radkova wpisują się w kierunki rozwoju bułgarskiej historiografii oraz światowej bizantynistyki XX wieku ${ }^{37}$. W swoich dramatach i poezji autor buduje świat przedstawiony w dyskursie uniwersalizmu bizantyjsko-słowiańskiej cywilizacji. Jego książka poetycka Bizantyjskie zapevi, jak i niektóre utwory dramaturgiczne obrazują nie tyle historyczne Bizancjum, ile idealne, takie jakie było w założeniu, ziemskie odzwierciadlenie Boskiego świata. Chrześcijańskie imperium Boga, które łączyło plemiona i narody pod znakiem Świętej Trójcy, a państwo i kultura - stanowiły syntezę świata antycznego i chrześcijańskiego

34 Tamże.

${ }^{35}$ W tym okresie Teatr Dawny już przestał istnieć, rozwiązany został przez ówczesne władze. Poecie i aktorom udało się jednak zebrać zespół i wyjechali do Rzymu.

36 Е. Георгиева, Личности.

37 W szerszym zakresie reprezentują pokrewieństwo z niektórymi ideami prof. Ivana Dujčeva i jego koncepcją „,wspólnoty słowiańsko-bułgarsko-bizantyjskiej”. Nawiązują również do ujęć historiozoficznych prof. Johna Meyendorffa, opartych na pojmowaniu konfesyjnego uniwersalizmu prawosławia. Wprowadził on do obiegu naukowego pojęcie ,,prawosławno-bizantyjskiej oikoumene”, podkreślające religijno-wyznaniowy charakter bizantyjsko-słowiańskiej cywilizacji. Zob. między innymi: J. Meyendorff, Byzantium and rise of Russia. A Study of Byzantino-Russian Relations in the Fourteenth Century, Cambridge 1981, s. 106; J. Meyendorff, Cultural ties: Byzantium, the Southern Slavs and Russia [w:] Byzantium and rise of Russia. A Study..., s. 116-138. Прот. Й. Мейендорф, Византия - Цьрквата и Империята, Византия и „другите”[w:] tenże, Византийската Цьрква, между небето и земята, thum. Б. Маринов, София 2007, s. 113-188; s. 226-243; s. 270-289; I. Dujčev, Slavia Orthodoxa: Collected Studies in the History of the Slavic Middle Ages, London 1970; Ив. Дуйчев, Избрани произведения в два тома. Исторически етюди: Византия и славянския свят, т. 1, София 1998); w języku polskim studium prof. Vassila Giuzeleva: Wptywy bizantyńskie w średniowiecznej kulturze bułgarskiej, thum. K. Marinow, „Przegląd Nauk Historycznych” 2010, rocznik VIII, nr 1, s. 5-17. 
ideału. Dla poety istota Bizancjum ukryta była w Kościele, jawiła się w postaci „liturgicznej ojczyzny piękna, przesiąkniętej hymnami i morzem"38. Dzisiaj współczesnemu odbiorcy trudno sobie wyobrazić podobne ujęcie tematu, ponieważ nie posiada on doświadczenia liturgicznego pisarza, które zostało wkomponowane w tkankę wierszy i słowa dramaturgicznego. Radkov pojmował słowo w kontekście majestatycznej poezji tekstów hymnografii bizantyjskiej i starobułgarskiej, w symbolicznym sensie każdego gestu podczas liturgii. Liturgia i jej Słowo dla poeta były realnym wcieleniem Logosu, muzyka i śpiewy hymniczne, o których Grzegorz z Nyssy pisał, że „filozofia zawarta w melodii posiada o wiele głębsze tajemnice, niż uważa zwykły lud" 39 .

„Prześladowania” inscenizacji Theophano związane są z trzema podstawowymi paradygmatami, które twórczość Radko Radkova jako całość naruszała. Po pierwsze, całkowicie nie mogła być wpisana w ideologiczny antyreligijny paradygmat „socjalistycznej kultury i literatury". Po drugie, utwory Radkova podważały paradygmat antybizantynizmu, po trzecie dramat historyczny w konwencji normatywnej literatury posiadał status poważnego, monumentalnego dzieła z podtekstem ideologicznym, a w mniemaniu ówczesnej krytyki sztuka Theophano została zrealizowana według wzoru widowiska typu hollywoodzkiego.

Twórczość Radkova jest osamotnionym przypadkiem w teatrze bułgarskim w ciągu ponad pięciu dekad. Dzisiaj pisze się o ekscentrycznym poecie, o jego problemach z władzą, jednak jeszcze nie powstała żadna praca, dotycząca dziedzictwa poetyckiego i dramaturgicznego Radkova. Dziedzictwo to jest trudne do zaszufladkowania i być może też nie do końca zrozumiałe. Współcześnie, już z innych powodów, związanych z sekularyzacją i neoliberalizmem, również obca jest nam kultura liturgiczna. Radko Radkov zdekonstruował w trudnych czasach kilka podstawowych kulturowo-estetycznych i ideologicznych nakazów władzy i krytyki normatywnej, poprzez swoją twórczość przeciwstawił się generalnej reinterpretacji przeszłości.

\section{Bibliografia}

Александров Е., Култура и лична власт. Аз работих с Людмила, София 1991.

Assman A., Między historią a pamięcią. Antologia, M. Saryusz-Wolska (red.), Warszawa 2013.

Саев Г., История на българския театър. От Освобождението до 1904 г., т. II, София 1997.

След 65 един актьор започна да играе само себе си, http://obshtestvo.net/\%60/ [odczyt: 6.06.2016].

Стефанов, История на българския театър. От зараждането до 1878 г., т. I, София 1997.

Стойчева Ц., Митева Ел., Интервю, „БТА-Паралели”, 17-23 декември, 1981, с. 6.

Стойчева Ц., Митева Ел., Интервю, „БТА-Паралели”, 17-23 декември, 1981, с. 6.

38 Por: Кр. Куюмджиев, Писма до г-жа N. [w:] Р. Радков, Византийски запеви. Стихове, s. 14.

${ }^{39}$ Суt. za: Кр. Куюмджиев, Писма до г-жа N., s. 14 (5-51). 
Дякон Л., История, Увод, превод и бележки Г. Цанкова [w:] Гръцки извори за българската история (Fontes graeci historiae Bulgaricae), т. V, Ив. Дуйчев (ред), София 1964, s. 245$276(257-258)$.

Diehl Ch., Théophano [w:] Figures Byzantines, Paris 1906, s. 217-243.

Dujčev I., Slavia Orthodoxa: Collected Studies in the History of the Slavic Middle Ages, London 1970 ;

Дуйчев Ив., Избрани произведения в два тома. Исторически етюди: Византия и славянския свят, т. 1, София 1998.

Дуйчев И., Български художник, София 1963.

Георгиева Е., Личности, „Над петдесет и пет”, 19 декември - 2 януари 2005.

Giuzelev V., Wpływy bizantyńskie w średniowiecznej kulturze bułgarskiej, thum. K. Marinow, „Przegląd Nauk Historycznych” 2010, rocznik VIII, nr 1, s. 5-17.

Geertz C., Interpretacja kultur. Wybrane eseje, tłum. M.M. Piechaczek, Kraków 2005.

Йорданов Н., Попилиев Р., Николова К., Дечева В., История на българския театър, т. IV, София 2011.

Иванов Й., Кръчмарка Теофана [w:] Старобългарски разкази. Разказ за ичар Фока и за братята му, как ги погуби в една нощ кръчмарката Теофана, София 1936, s. 187-189

Летописта на Константин Манасий. Фототипно издание на Ватиканския препис на среднобългарския превод (Biblioteca Apostolica Vaticana. Manuscript Vat. Slav II).

Meyendorff J., Byzantium and rise of Russia. A Study of Byzantino-Russian Relations in the Fourteenth Century, Cambridge 1981.

Meyendorff J., Cultural ties: Byzantium, the Southern Slavs and Russia [w:] Byzantium and rise of Russia. A Study of Byzantino-Russian Relations in the Fourteenth Century, Cambridge 1981.

Мейендорф Й., Византия - Църквата и Империята, Византия и „другите” [w:] tenże, Византийската Църква, между небето и земята, thum. Б. Маринов, София 2007, s. 113-188.

Obolensky D., The Byzantine Commonwealth: Eastern Europe, 500-1453. History of Civilization, London 1971.

Ostrogorski G., Dzieje Bizancjum, tłum. pod red. H. Ebert-Kappesowej, Warszawa 1968

Райчев М., Опорните точки на Слово за Търновград, „Народна култура”, бр. 21, 24 май 1979, s. 6.

Рашеева Г., Интересен творчески експеримент, „Димитровско знаме”, 8 август, 1981, s. 4.

Рашееева Г., Френски режисьор ще постави българска пиеса в театър „Боян Дановски”, „Димитровско знаме”, 17 юли 1981, s. 4.

Русинова Кр., Ще се пробуди ли спящата красавица, „Театър”, бр. 8/XXXV, София 1982.

Said E.W., Kultura i imperializm, tłum. M. Wyrwas-Wiśniewska, Kraków 2009.

Szynkareczka Theofano, thum. T. Dąbek-Wirgowa [w:] Siedem niebios i ziemia. Antologia dawnej prozy bułgarskiej, wstęp i tłum. T. Dąbek-Wirgowa, Warszawa 1983, s. 149-151.

Тошева Кр., История на българския театър. От 1904 до 1918 г., т. III, София 1997. 